\title{
PENGARUH KESESUAIAN KOMPENSASI, KOMITMEN ORGANISASI DAN BUDAYA ORGANISASI TERHADAP KEADILAN DISTRIBUTIF DI DINAS KABUPATEN BANYUMAS
}

\author{
NANDA PUTRI \\ ELIADA HERWIYANTI \\ WARSIDI \\ Fakultas Ekonomi dan Bisnis Universitas Jenderal Soedirman Purwokerto \\ elly_idc@yahoo.com
}

\begin{abstract}
This research is a quantitative research that was conducted in Banyumas Regency. The purpose of this research is to determine the effect of compensation suitability, organizational commitment and organizational culture to distributive justice. Hypothesis testing in this research using the method of multiple linear regression analysis. The population in this research are all Financial Officer in Banyumas Regency. Samples were taken using purposive sampling technique and Slovin Formula to determining the sample size, thus there are 52 samples in this research. Data was collected trough questionnaires to all of the respondents. Based on the results, it shown that the compensation suitability, organizational commitment, and organizational culture have a positive coefficient on distributive justice. All three independent variables simultaneously influenced to distributive justice, whereas the most influential variable is compensation suitability. It can be conclude that the higher level of compensation suitability, organizational commitment, and organizational culture, the higher level of distributive justice.
\end{abstract}

Keywords: Compensation suitability, organizational commitment, organizational culture, distributive justice

Abstrak: Penelitian adalah penelitian kuantitatif yang dilakukan di Kabupaten Banyumas. Tujuan penelitian adalah untuk mengetahui pengaruh kesesuaian kompensasi, komitmen organisasi dan budaya organisasi terhadap keadilan distributif. Pengujian hipotesis dalam penelitian ini menggunakan metode analisis regresi linier berganda. Populasi dalam penelitian ini adalah seluruh Petugas Keuangan di Kabupaten Banyumas. Sampel diambil dengan menggunakan teknik purposive sampling dan Slovin Formula untuk menentukan ukuran sampel, sehingga ada 52 sampel dalam penelitian ini. Data dikumpulkan melalui kuesioner kepada semua responden. Berdasarkan hasil, itu menunjukkan bahwa kesesuaian kompensasi, komitmen organisasi, dan budaya organisasi memiliki koefisien positif pada keadilan distributif. Ketiga variabel independen tersebut secara simultan berpengaruh terhadap keadilan distributif, sedangkan variabel yang paling berpengaruh adalah kesesuaian kompensasi. Dapat disimpulkan bahwa semakin tinggi tingkat kesesuaian kompensasi, komitmen organisasi, dan budaya organisasi, semakin tinggi tingkat keadilan distributif.

Kata kunci: Kesesuaian kompensasi, komitmen organisasi, budaya organisasi, keadilan distributif 


\section{PENDAHULUAN}

Kondisi organisasi sektor publik saat ini masih dicirikan oleh adanya fenomenafenomena yang kurang menguntungkan seperti: rendahnya komitmen dan konsistensi terhadap visi dan misi, banyaknya kasus-kasus inefisiensi dan KKN, mutu pelayanan yang masih rendah, serta kepemimpinan birokrasi belum dapat menjadi sumber inspirasi dan keteladanan. Berbagai permasalahan tersebut disebabkan oleh banyak faktor, salah satunya yaitu keadilan organisasi. Keadilan organisasi terdiri dari tiga bagian, yaitu keadilan prosedural yang mengacu pada proses yang digunakan dalam pembuatan keputusan, keadilan distributif yang mengacu pada imbalan yang dialokasikan di antara karyawan, keadilan interaksional yang mengacu hubungan antar pribadi dalam penentuan keluaran organisasi (Greenberg dan Baron, 2003, dalam Irawan, 2015). Dari ketiga keadilan organisasi tersebut, keadilan distributif cukup berpengaruh dengan kinerja organisasi. Menurut Wiryanata (2014), dikatakan bahwa keadilan distributif berpengaruh positif signifikan terhadap kinerja organisasi.

Keadilan distributif merupakan bentuk keadilan antara apa yang telah dikerjakan dengan hasil yang diperoleh. Hal ini berkaitan dengan gaji yang diperoleh para pegawai. Gaji dan tunjangan Pegawai Negeri Sipil (PNS) sudah diatur dalam Undang-Undang Nomor 5 Tahun 2014 tentang Aparatur Sipil Negara (ASN) yang mengatakan bahwa pemerintah wajib membayar gaji yang adil dan layak kepada PNS serta menjamin kesejahteraan PNS. Komponen gaji yang diterima PNS berdasarkan UU ASN tersebut terdiri dari 3 macam yaitu gaji, tunjangan kinerja, dan tunjangan kemahalan. Tunjangan Kemahalan disebutkan dalam pasal 80 ayat 4 yang berbunyi: Tunjangan kemahalan sebagaimana dimaksud pada ayat (2) dibayarkan sesuai dengan tingkat kemahalan berdasarkan indeks harga yang berlaku di daerah masing-masing. Ketentuan lebih lanjut mengenai gaji, tunjangan kinerja, tunjangan kemahalan diatur dalam Peraturan Pemerintah.

Meskipun sudah diatur dalam UndangUndang, masih terjadi persepsi ketidakadilan gaji dalam sektor publik. Misalnya gaji terrendah PNS Jakarta pada awal kepemimpinan gubernur saat ini, yang jauh di atas rata-rata standar gaji PNS. Berdasarkan PP 34 tahun 2014 tentang Peraturan Gaji PNS, maka gaji terrendah yang bisa diterima PNS dengan masa kerja 0 tahun Gol la adalah Rp1.402.400,00 sedangkan tertinggi dengan masa kerja 32 tahun dan golongan IVe adalah Rp5.302.100,00. Tingginya gaji PNS DKI Jakarta yaitu karena tunjangan kinerja daerah (TKD), yang dimungkinkan dialokasikan oleh setiap Pemerintah Daerah dengan menyesuaikan kemampuan daerah masing-masing. Pemda DKI dengan PAD yang tinggi tentu sangat mampu untuk menggaji pegawainya di atas rata-rata standar gaji PNS.

Selain perbedaan gaji PNS di masingmasing daerah, pada awal bulan Januari 2017 juga terjadi keterlambatan gaji PNS di sejumlah daerah di Indonesia. Para PNS tersebut mengeluhkan tentang keterlambatan gaji yang seharusnya sudah mereka terima. Hal itu disebabkan adanya perampingan organisasi perangkat daerah di seluruh Indonesia, sehingga perangkat daerah yang baru belum bisa mencairkan anggaran terkait gaji pegawai. Berdasarkan Peraturan Pemerintah Nomor 18 Tahun 2016 tentang Efisensi dan Efektivitas, menyebutkan sejumlah daerah memotong struktur perangkat daerah. Dengan demikian, sejumlah perangkat kerja daerah ada yang dirampingkan, kemudian dilakukan penyesuaian. Namun hal tersebut tidak terjadi pada PNS di DKI Jakarta, lantaran perampingan sudah selesai saat dipimpin oleh pemimpin yang baru (Suwarno, 2014). Jadi dapat dikatakan keterlambatan tersebut karena ada perubahan dalam organisasi perangkat daerah.

Selain kecemburuan antar pegawai pemerintah daerah, kecemburuan dengan persepsi ketidakadilan juga sering dirasakan oleh PNS pemerintah daerah dengan pusat. 
Keluarnya Peraturan Menteri Keuangan (PMK) Nomor 72 Tahun 2016 tentang Uang Makan bagi pegawai ASN, banyak yang menganggap bahwa semua PNS termasuk PNS Daerah seperti guru-guru PNS akan menerima uang makan mulai tahun 2016. Namun PMK 72/2016 sebenarnya hanya menggantikan PMK 110/2010 mengenai ketentuan pembayaran uang makan bagi PNS Pusat. Berhubung telah diterbitkannya UU ASN, uang makan pun tidak hanya diberikan kepada PNS, tetapi kepada PPPK juga diberikan uang makan sehingga istilahnya diubah menjadi uang makan bagi pegawai ASN. Selain itu, uang makan yang dulunya bisa dibayarkan ke rekening bendahara pengeluaran, lalu diberikan secara tunai kepada pegawai, dengan adanya PMK 72/2016 ini tidak bisa lagi. Uang makan mulai tahun 2016 semuanya langsung masuk ke rekening pegawai yang bersangkutan, seperti gaji bulanan yang langsung masuk ke rekening pegawai (www.gajibaru.com, 2016).

Banyak PNS Daerah yang mengeluh dan protes bahwa gaji mereka lebih kecil dibandingkan dengan PNS Pusat. Selain tidak menerima tunjangan kinerja, mereka juga protes karena uang makan hanya diberikan kepada PNS Pusat. Mereka menganggap pemerintah kurang perhatian dengan nasib PNS daerah. Sebenarnya beberapa pemerintah daerah telah memberikan uang makan kepada PNS di daerahnya. Diberikan atau tidak diberikannya uang makan kepada PNS Daerah sampai dengan saat ini merupakan kewenangan dari pemerintah daerah masing-masing, karena gaji PNS daerah dibayarkan oleh daerah yang bersangkutan. Sampai saat ini, Kementerian Dalam Negeri memang belum mengatur secara khusus mengenai uang makan bagi PNS Daerah (www.gajibaru.com, 2016).

Tuntutan-tuntutan dan demo PNS tentang gaji seharusnya juga diikuti dengan peningkatan kinerja. Gaji merupakan bentuk imbalan kerja, maka gaji yang diterima juga harus sesuai dengan kinerjanya. Apabila PNS hanya menuntut kenaikan gaji dan tidak diikuti dengan peningkatan kinerja, maka akan merugikan negara. Kinerja PNS yang tidak sesuai dengan prosedur akan menyebabkan rendahnya kualitas birokrasi pemerintah. Misalnya para pegawai yang absen pada hari kerja, pulang kerja lebih awal dari waktu yang ditentukan, bekerja kurang teliti dan sebagainya. Pada Agustus 2012 PNS Pemerintah Kabupaten Banyumas banyak yang absen di hari pertama usai libur lebaran. Selain itu banyak juga yang telat datang apel pagi yang digelar di halaman Pemkab Banyumas. Namun demikian Bupati Banyumas pada saat itu, Mardjoko mengatakan bahwa para PNS yang tidak disiplin akan dikenakan tindakan-tindakan sesuai sanksi dari peraturan kepegawaian yang ada, apakah akan dikurangi gajinya atau dipotong tunjangannya, kecuali mereka yang cuti. Tindakan atas ketidakdisiplinan PNS memang perlu dilakukan secara tegas untuk meningkatkan kinerja mereka.

Kinerja Pemkab Banyumas dinilai sudah cukup baik, sehingga pada tahun 2016 mendapatkan penghargaan Dana Rakca dari pemerintah pusat. Dana Rakca diterima Kabupaten Banyumas setelah pemerintah pusat, dalam hal ini Kementerian Keuangan RI melihat kinerja Kabupaten Banyumas dinilai sangat baik dalam pengelolaan keuangan daerah. Kabupaten Banyumas juga dinilai berprestasi, di antaranya mampu memperoleh opini Wajar Tanpa Pengecualian (WTP) sebanyak 5 kali atas Laporan Kinerja Pemerintah Daerah (LKPD) dari tahun 2011 sampai dengan 2015 (Edyano, 2016).

Berbagai hal yang terjadi dalam sektor publik tentu menimbulkan persepsi ketidakadilan, karena sistem penggajian di sektor publik menggunakan pangkat dan golongan. Jika gaji diukur dengan pangkat dan golongan, maka sistem gaji tersebut tidak berdasarkan seberapa besar kinerja pegawai. Bahkan pegawai pemerintah daerah dengan pangkat dan golongan sama, mendapat gaji yang berbeda sesuai dengan tunjangan kinerja daerah masing-masing. Sistem penggajian 
tersebut tentu berbeda dengan konsep keadilan distributif yang menyatakan bahwa hasil yang diterima berdasarkan kinerja yang telah dilakukan.

Mulai 2017, sistem penggajian bagi PNS di Kabupaten Banyumas dan daerah lain di Jateng tidak lagi mengacu pada pangkat dan golongan serta lama masa kerja. Namun disesuaikan dengan kelas jabatan, di antaranya dihitung dari kualitas kinerja dan capaian beban kerja di jabatan yang dipegang. Kepala Sub Bagian Analis Formasi dan Jabatan Biro Organisasi dan Kepegawaian Setda Pemprov Jateng, Wisnu Zaroh mengatakan, pelaksanaan penggajian dengan sistem tunjangan kinerja (renumeurasi) untuk pegawai pemprov ditargetkan April 2016. Sedangkan untuk kabupaten atau kota di Jateng diperkirakan mulai 2017, terutama untuk daerah-daerah yang dinilai sudah siap dan memiliki potensi PAD tinggi dan birokrasi yang sudah tertata dengan baik (www.suaramerdeka.com, 2015).

Penilaian dalam sistem gaji dengan kelas jabatan berbasis informasi teknologi (IT). Sistem IT yang akan memverifikasi apakah seorang pegawai melakukan pekerjaan sesuai dengan beban kinerja di jabatan itu atau tidak. Jika tidak memenuhi, sistem tersebut langsung menolak. Maka dari itu memerlukan waktu yang cukup lama dalam persiapan IT. Tunjangan kinerja ke depan tidak lagi didasarkan pada pangkat dan golongan. Namun berdasarkan kualitas dari beban kinerja yang dihasilkan. Sedangkan untuk pengisian jabatan struktural, mendasarkan pada lelang jabatan. Jadi pendapatan pegawai tiap bulan bisa naik, bisa turun, tergantung dari kinerja dan absensinya. Nanti sistem IT yang menghitung, apakah seoarang pegawai memenuhi standar yang diisyaratkan atau tidak dengan jabatan yang dipegang. Namun pada tahun 2015, Pemkab Banyumas belum bisa menerapkan sistem gaji berdasar kelas jabatan, karena baru melakukan validasi ke Badan Kepegawaian Nasional (BKN). Sedangkan provinsi yang sudah validasi satu setengah tahun saja, baru bisa menerapkan sistem tersebut tahun depannya.

Dalam penelitian ini akan diteliti faktorfaktor yang mempengaruhi keadilan distributif. Keadilan distributif merupakan suatu anggapan mengenai keadilan hasil dalam hubungannya dengan individu atau input kelompok khususnya dalam hal bagaimana individu mengevaluasi dan bereaksi terhadap perlakuan yang berbeda (Adams dalam Wiryanata, 2014). Keadilan distributif dapat memengaruhi kinerja organisasi. Agar dapat bekerja secara efisien dan efektif, organisasi membutuhkan informasi tentang (i) sumber daya yang dimilikinya, dan (ii) hasil yang telah dicapai dengan penggunaan sumber daya tersebut. Kebutuhan informasi dapat diperoleh dari sistem informasi akuntansi. Salah satu subsistem informasi akuntansi adalah akuntansi manajemen yang dapat menyediakan jasa inforrnasi akuntansi yang berguna untuk pengambilan keputusan para manajer (Sugiri, 2009). Salah satu keputusan manajer dalam kaitannya dengan kinerja karyawan yaitu pemberian kompensasi. Kompensasi adalah segala sesuatu yang diterima para karyawan sebagai balas jasa untuk kerja mereka (Handoko, 2003, p.114-118). Keadilan kompensasi telah menjadi isu sentral yang banyak dibahas dalam berbagai literatur sumber daya manusia (Suhartini, 1999, p.113; Babakus et.al., 1996, dalam Retnaningsih, 2007). Kompensasi yang sesuai akan meningkatkan keadilan dalam sebuah organisasi.

Hal berikutnya yang berkaitan dengan keadilan distributif yaitu komitmen organisasi. Komitmen organisasi adalah kemauan atau keinginan yang kuat dari anggota organisasi untuk tetap berada, bekerja, dan memiliki rasa terhadap organisasi (Hwei dan T.Elizabeth, 2012). Dengan demikian komitmen organisasi dapat dikatakan sebagai loyalitas dari anggota organisasi tersebut. Komitmen yang kuat akan mendorong tingkat keadilan dalam organisasi, karena anggota organisasi tersebut bekerja dengan sungguh-sungguh agar tujuan organisasi tercapai. Pada penelitian Thorn 
(2010) dalam Rejeki (2015), mengatakan bahwa keadilan organisasi, kepuasan kerja dan komitmen organisasional saling berhubungan.

Keadilan distributif berkaitan dengan perilaku manusia dalam organisasi tersebut, karena setiap individu dalam menentukan keadilan akan membandingkan input dan hasil diri sendiri dengan orang lain. Perilaku seseorang dalam sebuah organisasi biasanya dipengaruhi oleh budaya organisasi tersebut. Secara umum budaya organisasi didefinisikan sebagai serangkaian tata nilai, keyakinan, dan pola-pola perilaku yang membentuk identitas organisasi serta perilaku para anggotanya (Deshpande dan Farley, 1999, dalam Nugroho, 2006). Dapat dikatakan bahwa budaya organisasi juga berpengaruh terhadap keadilan distributif.

Pada penelitian-penelitian sebelumnya, keadilan distributif dijadikan sebagai variabel dependen atau variabel yang mempengaruhi. Dalam penelitian Wiryanta (2014) yang mengatakan bahwa keadilan distributif pada kinerja organisasi menunjukkan hasil yang positif dan signifikan. Sedangkan dalam penelitian Sutrisna (2014), mengatakan bahwa ketiga konsep keadilan organisasi memang benar mampu mempengaruhi kepuasan kerja seorang paramedis.

\section{Teori Keadilan}

Teori yang mendasari penelitian ini yaitu teori keadilan. Teori keadilan sudah ada sejak zaman dahulu kala. Oleh sebab itu teori keadilan dibagi ke dalam empat kategori yaitu Teori Keadilan Klasik, Teori Keadilan Abad Pertengahan, Teori Keadilan Modern, dan Teori Keadilan Kontemporer. Sedangkan Aristoteles (384-322 SM) menyatakan bahwa keadilan merupakan aktivitas memberikan sesuatu kepada orang lain (kewajiban) setara dengan apa yang kita dapatkan dari orang lain (hak). Aristoteles mengklasifikasikan keadilan menjadi lima jenis yaitu keadilan distibutif, keadilan komunikatif, keadilan perbaikan, keadilan konvensional dan kodrat alam.

\section{Keadilan Distributif}

Secara konseptual, keadilan distributif berkaitan dengan distribusi keadaan dan barang yang akan berpengaruh terhadap kesejahteraan individu, yang meliputi aspek fisik, psikologis, ekonomi dan sosial (Herwiyanti, 2006). Beberapa faktor yang dapat mempengaruhi keadilan distributif yaitu kesesuaian kompensasi, komitmen organisasi dan budaya organisasi

Kompensasi merupakan faktor penting yang mempengaruhi bagaimana dan mengapa seseorang bekerja pada suatu organisasi dan bukan pada organisasi lainnya (Retnaningsih, 2007). Menurut Equity Theory, hasil sesuai dengan input yang berarti kompensasi yang diterima pegawai diharapkan sesuai dengan kinerjanya. Apabila kompensasi yang diberikan sesuai, maka dapat meningkatkan kinerja karyawan dan meningkatkan keadilan distributif. Komitmen Organisasi merupakan derajat seseorang mengidentifikasi dirinya sebagai bagian dari organisasi dan berkeinginan melanjutkan partisipasi aktif di dalamnya (Retnaningsih, 2007). Pegawai yang berkomitmen tinggi terhadap organisasinya pasti bekerja dengan sungguh-sungguh, sehingga komitmen organisasi dapat meningkatkan kinerja dan meningkatkan keadilan distributif.

Kotter dan Heskett (1997) dalam Pratiwi (2012) mengatakan bahwa budaya yang kuat dapat menghasilkan efek yang sangat mempengaruhi individu dan kinerja, bahkan dalam suatu lingkungan bersaing pengaruh tersebut dapat lebih besar daripada faktor- faktor lain seperti struktur organisasi, alat analisis keuangan, kepemimpinan dan lain -lain. Budaya organisasi yang mudah menyesuaikan dengan perubahan jaman (adaptif) adalah yang dapat meningkatkan kinerja. Peningkatan kinerja tersebut akan berdampak pada meningkatnya keadilan distributif dalam organisasi. Ketiga faktor tersebut diduga mempunyai pengaruh secara simultan terhadap keadilan distributif, maka dapat dibangun hipotesis sebagai berikut: 
$\mathrm{H} 1$ : Kesesuaian Kompensasi, Komitmen Organisasi, dan Budaya Organisasi berpengaruh secara simultan terhadap Keadilan Distributif.

\section{Kesesuaian Kompensasi}

Menurut Long (1998:8) dalam bukunya Compensation in Canada mendefinisikan sistem kompensasi adalah bagian (parsial) dari sistem reward yang hanya berkaitan dengan bagian ekonomi, namun demikian sejak adanya keyakinan bahwa perilaku individual dipengaruhi oleh sistem dalam spektrum yang lebih luas maka sistem kompensasi tidak dapat terpisah dari keseluruhan sistem reward yang disediakan oleh organisasi.

Kompensasi yang diharapkan karyawan tentunya yang sesuai dengan kinerjanya. Untuk menganggap kompensasi tersebut sesuai atau tidak, biasanya seseorang akan membandingkan dengan orang lain. Membandingkan dapat dengan anggota dalam organisasi tersebut atau dengan organisasi lain. Misalnya saja pegawai pemda membandingkan dirinya dengan pegawai di pemda yang sama maupun pegawai pemda lain, atau bahkan membandingkan dengan pegawai pemerintah pusat. Ketika dibandingkan tidak sesuai maka akan timbul ketidakadilan dalam pendistribusian kompensasi tersebut. Oleh sebab itu kesesuaian kompensasi dapat mempengaruhi tingkat keadilan distributif. Berdasarkan uraian tersebut, maka dapat dibangun hipotesis sebagai berikut: $\mathrm{H} 2$ : Kesesuaian kompensasi berpengaruh positif terhadap keadilan distributif.

\section{Komitmen Organisasi}

Colquitt et al. (2009) mendefinisikan komitmen organisasional sebagai keinginan dari karyawan untuk menjadi bagian dan anggota di suatu organisasi. Komitmen terhadap organisasi artinya lebih dari sekedar keanggotaan formal, karena meliputi sikap menyukai organisasi dan upaya yang lebih tinggi bagi kepentingan organisasinya dalam mencapai tujuan (Rejeki, 2015).
Komitmen organisasi merupakan bentuk psikologis anggota organisasi yang mempunyai keyakinan kuat akan tujuan dan nilai-nilai organisasi, kemauan yang kuat untuk bekerja sepenuhnya serta keinginan untuk tetap berada dalam organisasi tersebut. Dengan merasa menjadi bagian penting dalam organisasi, akan mendorong seseorang untuk bertindak adil sesuai dengan ketentuan yang berlaku guna mencapai tujuan organisasi. Sehingga komitmen organisasi dapat meningkatkan keadilan distributif. Berdasarkan uraian tersebut, maka dapat dibangun hipotesis sebagai berikut:

H3: Komitmen organisasi berpengaruh positif terhadap keadilan distributif.

\section{Budaya Organisasi}

Secara umum budaya organisasi didefinisikan sebagai serangkaian tata nilai, keyakinan, dan pola-pola perilaku yang membentuk identitas organisasi serta perilaku para anggotanya (Deshpande \& Farley, 1999, dalam Nugroho, 2006). Dari definisi tersebut, budaya organisasi mengarah pada dua hal yaitu nilai dan norma perilaku anggotanya.

Budaya organisasi yang baik tidak hanya meningkatkan kinerja karyawan, tetapi juga dapat meningkatkan keadilan distributif. Jika di suatu organisasi tidak tercipta keadilan distributif, maka akan terus-menerus ke generasi berikutnya. Budaya organisasi yang baik akan dapat memperbaiki birokrasi sektor publik yang selama ini masih terdapat fenomena-fenomena yang kurang menguntungkan. Maka dari itu perlu adanya budaya organisasi yang baik yang sesuai dengan prosedur atau peraturan yang berlaku. Berdasarkan uraian tersebut, maka dapat dibangun hipotesis sebagai berikut:

$\mathrm{H} 4$ : Budaya organisasi berpengaruh positif terhadap keadilan distributif. 


\section{Kesesuaian Kompensasi Paling Berpengaruh terhadap Keadilan Distributif}

Kesesuaian kompensasi merupakan pemberian kompensasi yang sesuai dengan kinerjanya. Konsep tersebut sesuai dengan Equithy Theory yang menyebutkan bahwa hasil yang didapat sesuai dengan input yang dikerjakan. Jika kompensasi yang diberikan sudah sesuai dengan kinerja, maka dapat dikatakan adil. Sesuatu dikatakan adil atau tidaknya yaitu dengan membandingkan hasil dan input.

Dari ketiga faktor yaitu kesesuaian kompensasi, komitmen organisasi dan budaya organisasi, faktor kesesuaian kompensasi diduga yang paling berpengaruh terhadap keadilan distributif. Pada dasarnya untuk mengukur tingkat keadilan yaitu dengan membandingkan hasil yang didapat yaitu berupa kompensasi, dengan input yang telah dikerjakan. Berdasarkan uraian tersebut, maka dapat dibangun hipotesis sebagai berikut:
H5: Kesesuaian kompensasi paling berpengaruh terhadap keadilan distributif.

Penelitian terdahulu dapat dilihat pada tabel 1.

\section{METODE PENELITIAN}

Populasi dalam penelitian ini pegawai sub bagian keuangan pada masing-masing Dinas Kabupaten Banyumas. Metode pengambilan sampel dalam penelitian ini adalah dengan purposive sampling. Purposive Sampling adalah teknik penentuan sampel dengan berdasarkan kriteria-kriteria atau pertimbangan tertentu (Sugiyono, 2012:117). Dari perhitungan tersebut didapat ukuran sampel minimal dalam penelitian ini sebanyak 42. Pembagian sampel dilakukan secara proporsional untuk masing-masing dinas Kabupaten Banyumas dengan menggunakan teknik Proportionate Stratified Random sampling. Definisi Operasional dan Pengukuran Variabel berikut:

Tabel 1 Penelitian Terdahulu

\begin{tabular}{|c|c|c|}
\hline $\begin{array}{l}\text { Peneliti } \\
\text { (tahun) }\end{array}$ & Variabel & Hasil \\
\hline $\begin{array}{l}\text { Sudarwanti Retnaningsih } \\
\text { (2007) }\end{array}$ & $\begin{array}{l}\text { Variabel Dependen: } \\
\text { Kinerja Organisasi. } \\
\text { Variabel Independen: } \\
\text { a. Keadilan kompensasi } \\
\text { b. Peran Kepemimpinan } \\
\text { c. Kepuasan Kerja. } \\
\text { Variabel Intervening: } \\
\text { Komitmen organisasi. }\end{array}$ & $\begin{array}{l}\text { Keadilan kompensasi lebih } \\
\text { berpengaruh terhadap komitmen } \\
\text { organisasi dibandingkan dengan } \\
\text { peran kepemimpinan dan } \\
\text { kepuasan kerja sehingga komitmen } \\
\text { organisasi lebih berpengaruh } \\
\text { terhadap kinerja. }\end{array}$ \\
\hline $\begin{array}{l}\text { Rakhmat Nugroho } \\
\text { (2006) }\end{array}$ & $\begin{array}{l}\text { Variabel Dependen: } \\
\text { Kinerja Organisasi. } \\
\text { Variabel Independen: } \\
\text { a. Kepemimpinan } \\
\text { b. Budaya organisasi. }\end{array}$ & $\begin{array}{l}\text { Terdapat pengaruh yang positif dan } \\
\text { signifikan antara Kepemimpinan } \\
\text { dan Kinerja karyawan. } \\
\text { Terdapat pengaruh yang signifikan } \\
\text { antara Budaya Organisasi terhadap } \\
\text { kinerja karyawan. } \\
\text { Terdapat pengaruh yang signifikan } \\
\text { antara variabel moderate (interaksi } \\
\text { X1 dan X2) terhadap kinerja } \\
\text { karyawan }\end{array}$ \\
\hline
\end{tabular}




\begin{tabular}{|c|c|c|}
\hline $\begin{array}{l}\text { I Gusti Ngurah Agung } \\
\text { Wiryanata } \\
\text { (2014) }\end{array}$ & $\begin{array}{l}\text { Variabel Dependen: } \\
\text { Kinerja Organisasi. } \\
\text { Variabel Independen: } \\
\text { a. Partisipasi Anggaran } \\
\text { b. Keadilan Prosedural } \\
\text { c. Keadilan Distributif } \\
\text { d. Goal Commitment. }\end{array}$ & $\begin{array}{l}\text { Secara empiris, partisipasi } \\
\text { anggaran berpengaruh positif pada } \\
\text { kinerja organisasi. Persepsi } \\
\text { keadilan prosedural menunjukkan } \\
\text { adanya hasil yang positif dan } \\
\text { signifikan pengaruh pada kinerja } \\
\text { organisasi. Sedangkan keadilan } \\
\text { distributif pada kinerja organisasi } \\
\text { menunjukkan hasil yang positif dan } \\
\text { signifikan. }\end{array}$ \\
\hline $\begin{array}{l}\text { I Wayan Wira Sutrisna dan } \\
\text { Agoes Ganesha Rahyuda } \\
\text { (2014) }\end{array}$ & $\begin{array}{l}\text { Variabel Dependen: } \\
\text { a. Kepuasan Kerja } \\
\text { b. Komitmen Organisasi. } \\
\text { Variabel Independen: } \\
\text { a. Keadilan Distributif } \\
\text { b. Keadilan Prosedural } \\
\text { c. Keadilan Interaksional. }\end{array}$ & $\begin{array}{l}\text { Ketiga konsep keadilan organisasi } \\
\text { memang benar mampu } \\
\text { mempengaruhi kepuasan kerja } \\
\text { seorang paramedis. }\end{array}$ \\
\hline $\begin{array}{l}\text { Anggraeni Tri Rejeki } \\
\text { (2015) }\end{array}$ & $\begin{array}{l}\text { Variabel Dependen: } \\
\text { Komitmen Organisasi. } \\
\text { Variabel Independen: } \\
\text { Keadilan Organisasional. } \\
\text { Mediasi: } \\
\text { Kepuasan Kerja. }\end{array}$ & $\begin{array}{l}\text { Keadilan organisasional } \\
\text { mempunyai pengaruh positif dan } \\
\text { signifikan pada kepuasan yang } \\
\text { ditunjukkan karyawan. } \\
\text { Kepuasan kerja mempunyai } \\
\text { pengaruh positif dan signifikan } \\
\text { pada komitmen organisasional } \\
\text { Keadilan organisasional tidak } \\
\text { mempunyai pengaruh signifikan } \\
\text { pada komitmen organisasi } \\
\text { Kepuasan kerja memediasi } \\
\text { pengaruh antara keadilan } \\
\text { organisasional pada komitmen } \\
\text { organisasional }\end{array}$ \\
\hline
\end{tabular}

Tabel 2 Definisi Operasional Variabel dan Pengukurannya

\begin{tabular}{|c|c|c|c|}
\hline Variabel & Definisi Operasional & Indikator & Skala \\
\hline Kesesuaian & Faktor penting yang & 1) Kenaikan Gaji & Likert \\
\hline \multirow{6}{*}{$\begin{array}{l}\text { Kompensasi } \\
\text { (Variabel } \\
\text { Independen) }\end{array}$} & mempengaruhi & 2) Tunjangan & \multirow[t]{6}{*}{5 poin } \\
\hline & bagaimana dan mengapa & 3) Peluang Promosi & \\
\hline & seseorang bekerja pada & 4) Proses Penilaian Prestasi & \\
\hline & suatu organisasi dan & 5) Proses Penentuan Gaji & \\
\hline & bukan pada organisasi & 6) Proses Penentuan Promosi. & \\
\hline & $\begin{array}{l}\text { lainnya. } \\
\text { (Retnaningsih, 2007) }\end{array}$ & (Retnaningsih, 2007) & \\
\hline $\begin{array}{l}\text { Komitmen } \\
\text { Organisasi }\end{array}$ & $\begin{array}{l}\text { Derajat seseorang } \\
\text { mengidentifikasi dirinya }\end{array}$ & $\begin{array}{l}\text { 1. Perasaan menjadi bagian dari } \\
\text { organisasi. }\end{array}$ & $\begin{array}{l}\text { Likert } \\
5 \text { poin }\end{array}$ \\
\hline & & & \\
\hline
\end{tabular}




\begin{tabular}{|c|c|c|c|}
\hline $\begin{array}{c}\text { (Variabel } \\
\text { Independen) }\end{array}$ & $\begin{array}{l}\text { organisasi dan } \\
\text { berkeinginan melanjutkan } \\
\text { partisipasi aktif di } \\
\text { dalamnya. } \\
\text { (Retnaningsih, 2007) }\end{array}$ & $\begin{array}{l}\text { 3. Kepedulian terhadap organisasi. } \\
\text { 4. Hasrat yang kuat untuk bekerja } \\
\text { pada organisasi. } \\
\text { 5. Kepercayaan yang kuat terhadap } \\
\text { nilai-nilai organisasi. } \\
\text { 6. Kemauan yang besar untuk } \\
\text { berusaha bagi organisasi. } \\
\text { (Retnaningsih, 2007) }\end{array}$ & \\
\hline $\begin{array}{c}\text { Budaya } \\
\text { Organisasi } \\
\text { (Variabel } \\
\text { Independen) }\end{array}$ & $\begin{array}{l}\text { Budaya Organisasi } \\
\text { mencerminkan orientasi } \\
\text { perilaku yang seimbang } \\
\text { antara mementingkan } \\
\text { karyawan (people- } \\
\text { oriented) dengan } \\
\text { mementingkan tugas } \\
\text { (task-oriented) untuk } \\
\text { mencapai tujuan } \\
\text { organisasi melalui } \\
\text { pengembangan sumber } \\
\text { daya manusia (Cooke \& } \\
\text { Szumal, 1993; Pool, } \\
\text { 2003). }\end{array}$ & $\begin{array}{l}\text { 1. Kualitas hasil pekerjaan lebih } \\
\text { utama dari kuantitas } \\
\text { 2. Kreativitas dan inovasi mendapat } \\
\text { penghargaan yang tinggi } \\
\text { 3. Kerjasama dan kebersamaan antar } \\
\text { karyawan maupun atasan } \\
\text { 4. Penyelesaian konflik } \\
\text { 5. Saling memotivasi dan mengkrtik } \\
\text { antar karyawan } \\
\text { 6. Kepatuhan terhadap kebijakan \& } \\
\text { peraturan organisasi. } \\
\text { (Nugroho, 2006) }\end{array}$ & $\begin{array}{l}\text { Likert } \\
5 \text { poin }\end{array}$ \\
\hline $\begin{array}{l}\text { Keadilan } \\
\text { Distributif } \\
\text { (Variabel } \\
\text { Dependen) }\end{array}$ & $\begin{array}{l}\text { Secara konseptual, } \\
\text { keadilan distributif } \\
\text { berkaitan dengan } \\
\text { distribusi keadaan dan } \\
\text { barag yang akan } \\
\text { berpengaruh terhadap } \\
\text { kesejahteraan individu, } \\
\text { yang meliputi aspek fisik, } \\
\text { psikologis, ekonomi dan } \\
\text { sosial. } \\
\text { (Herwiyanti, 2006) }\end{array}$ & $\begin{array}{l}\text { 1. Jadwal kerja } \\
\text { 2. Beban kerja } \\
\text { 3. Penghargaan yang didapatkan } \\
\text { 4. Tanggung jawab pekerjaan. } \\
\text { (Irawan, 2015) }\end{array}$ & $\begin{array}{l}\text { Likert } \\
5 \text { poin }\end{array}$ \\
\hline
\end{tabular}

Metode analisis data yang digunakan dalam penelitian ini adalah metode regresi linear berganda yang dirumuskan sebagai berikut:

$\begin{array}{ll}\mathrm{Y}=\mathrm{a}+\beta_{1} X_{1}+ & \beta_{2} X_{2}+\beta_{3} X_{3}+\mathrm{e} \\ \text { Keterangan: } & \\ \mathrm{Y} & =\text { Keadilan Distributif } \\ X_{1} & =\text { Kesesuaian Kompensasi } \\ X_{2} & =\text { Komitmen Organisasi } \\ X_{3} & =\text { Budaya Organisasi } \\ \beta_{1}, \beta_{2}, \beta_{3} & =\text { Koefisien Regresi } \\ \mathrm{a} & =\text { Konstanta } \\ \mathrm{e} & =\text { Variabel gangguan }\end{array}$

\section{HASIL DAN PEMBAHASAN}

Hasil pengujian hipotesis pertama dengan menggunakan uji $\mathrm{F}$ menunjukkan bahwa kesesuaian kompensasi, komitmen organisasi dan budaya organisasi berpengaruh secara bersama-sama (simultan) terhadap keadilan distributif. Berdasarkan hal tersebut maka ketiga variabel dapat digunakan untuk memprediksi persepsi keadilan distributif.

Berdasarkan hasil uji parsial (uji t) untuk hipotesis kedua, diketahui bahwa kesesuaian 
kompensasi berpengaruh secara positif terhadap keadilan distributif. Hal tersebut menunjukkan bahwa semakin tinggi tingkat kesesuaian kompensasi maka semakin tinggi pula tingkat keadilan distributif pada Dinas Kabupaten Banyumas. Kesesuaian kompensasi sama halnya dengan konsep keadilan distributif, jadi keadilan distributif akan meningkat ketika kompensasi yang diberikan sudah sesuai dengan pekerjaan yang telah dilakukan.

Berdasarkan hasil uji parsial (uji t) untuk hipotesis ketiga, diketahui bahwa kesesuaian kompensasi berpengaruh secara positif terhadap keadilan distributif. Hal tersebut menunjukkan bahwa semakin tinggi tingkat komitmen organisasi maka semakin tinggi pula tingkat keadilan distributif pada Dinas Kabupaten Banyumas.

Komitmen organisasi merupakan bentuk psikologis anggota organisasi yang mempunyai keyakinan kuat akan tujuan dan nilai-nilai organisasi, kemauan yang kuat untuk bekerja sepenuhnya serta keinginan untuk tetap berada dalam organisasi tersebut. Dengan merasa menjadi bagian penting dalam organisasi, akan mendorong seseorang untuk bertindak adil sesuai dengan ketentuan yang berlaku guna mencapai tujuan organisasi. Sehingga semakin tinggi tingkat komitmen organisasi maka semakin tinggi tingkat keadilan distributif.

Berdasarkan hasil uji parsial (uji t) untuk hipotesis ketiga, diketahui bahwa budaya organisasi berpengaruh secara positif terhadap keadilan distributif. Hal tersebut menunjukkan bahwa semakin meningkat budaya organisasi yang baik maka semakin tinggi pula tingkat keadilan distributif pada Dinas Kabupaten Banyumas.

Budaya organisasi dapat membentuk budaya kerja yang baik yang akan meningkatkan kinerja. Dengan kinerja yang baik maka keadilan distributif akan meningkat. Berdasarkan hasil uji elastisitas untuk hipotesis kelima, diketahui bahwa variabel kesesuaian kompensasi memiliki nilai elastisitas yang tinggi dibandingkan dengan variabel komitmen organisasi dan budaya organisasi $\left(E_{1}>\right.$ $\left.E_{2}, E_{3}\right)$, sehingga kesesuaian kompensasi yang paling berpengaruh terhadap keadilan distributif.

Menurut Equity Theory dijelaskan bahwa yang dimaksud keadilan distributif yaitu hasil yang diterima (berupa gaji, tunjangan dan sebagainya) sesuai dengan input yang dikerjakan. Menurut Robbins dan Timothy (2015), rencana pembayaran gaji berdasarkan hasil kerja (piece-rate pay plan) yaitu rencana pembayaran gaji yang mana para pekerja dibayar dalam jumlah yang tetap atas setiap unit produksi yang diselesaikan. Sedangkan pembayaran gaji dalam konteks kesesuaian kompensasi yang dimaksud yaitu pembayaran gaji yang sesuai berdasarkan prestasi. Menurut Robbins dan Timothy (2015), pembayaran gaji berdasarkan prestasi (merit-based pay plan) yaitu membayar gaji bagi kinerja individu yang didasarkan pada peringkat penilaian kinerja

Dari perbedaan konsep tersebut dapat dikatakan bahwa kesesuaian kompensasi dan keadilan distributif merupakan dua jenis variabel yang berbeda. Kesesuaian kompensasi yang paling berpengaruh terhadap keadilan distributif bukan karena kedua variabel tersebut memiliki konstruk yang sama.

\section{KESIMPULAN DAN IMPLIKASI}

Analisis data yang telah dilakukan dapat ditarik kesimpulan bahwa (1) kesesuaian kompensasi, komitmen organisasi, dan budaya organisasi berpengaruh secara bersama-sama (simultan) terhadap keadilan distributif; (2) Kesesuaian kompensasi berpengaruh positif signifikan terhadap keadilan distributif; (3) Komitmen organisasi berpengaruh positif signifikan terhadap keadilan distributif; (4) Budaya Organisasi berpengaruh positif signifikan terhadap keadilan distributif; (5) Kesesuaian kompensasi paling berpengaruh terhadap keadilan distributif. 
Berdasarkan analisis dan hasil penelitian di atas dapat diperoleh implikasi penelitian bahwa hasil penelitian ini diharapkan dapat digunakan sebagai pengembangan literatur-literatur akuntansi yang sudah ada, terutama di bidang akuntansi manajemen dan memperkuat penelitian sebelumnya yang berkaitan dengan keadilan distributif, serta dapat menambah referensi sebagai pembanding untuk penelitian yang akan datang.

Bagi Organisasi, hasil penelitian ini diharapkan dapat menjadi masukan bagi organisasi khususnya sektor publik dalam hal pengambilan keputusan dan pembuatan peraturan terkait sistem gaji pegawai. Gaji yang sesuai akan meningkatkan kinerja pegawai, khususnya kinerja keuangan dalam pembuatan laporan keuangan sebagai bentuk pertanggungjawaban. Bagi Regulator, hasil penelitian ini diharapkan dapat menjadi masukan bagi pemerintah selaku regulator, dalam hal pembuatan aturan tentang sistem gaji atau upah baik untuk sektor publik maupun sektor swasta.

Pada penelitian ini dimungkinkan terjadinya sampling error (bias) karena jumlah sampel yang terlalu sedikit atau perbedaan individu dalam pengisian kuesioner untuk variabel dependen dan independen yang diterapkan dalam penelitian ini. Subjektivitas dari responden seperti sikap, perasaan, emosi dan persepsi juga dapat mengakibatkan biasnya jawaban responden sehingga mempengaruhi hasil penelitian ini. Untuk mengurangi terjadinya sampling error (bias) pada suatu penelitian dapat dilakukan dengan menambah ukuran sampel.

\section{REFERENSI:}

Adams, J.S. 1965. Inequity in Social Exchange. In: L. Berkowitz (Ed). Advances in Experimental Social Psychology Vol.2, Edited by. L. Berkowitz. San Diego. CA: Academic Press.

Colquitt, J. A., LePine, J. A., \& Wesson, M. J. 2009. Organizational behavior: Improving performance and commitment in the workplace. United States: McGraw-Hill.

Edyano, Dicky. 2016. Pemkab Banyumas Raih Penghargaan Dana Rakca 2016. https://www.bangsaonline.com/berita/29159/pemkab-banyumas-raih-penghargaan-dana-rakca-2016, diakses pada 25 April 2017.

Gajibaru. 2016. Uang Makan PNS Daerah. http://www.gajibaru.com/2016/06/uang-makan-pns-daerah.html, diakses pada tanggal 9 april 2017.

Handoko, T. 2003. Manajemen. Edisi Kedua. BPFE, Yogyakarta.

Herwiyanti, Eliada. 2006. Organizational Justice di Kalangan Profesi Audit. Jurnal Akuntabel. Vol 1 No 1 halaman 24-32.

Hwei, She, T.Elizabeth Cintya Santosa. 2012. Pengaruh Keadilan Prosedural dan Keadilan Distributif terhadap Komitmen Organisasi. Jurnal Ekonomika dan Bisnis Vol. 9 No. 2 Oktober 2012.

Irawan, Luthfi. 2015. Pengaruh Keadilan Distributif dan Keadilan Prosedural pada Komitmen Afektif dengan Kepuasan Kerja sebagai Variabel Mediasi (Studi pada Karyawan PT Tanjung Kreasi Parquet Industry Temanggung). Skripsi. Universitas Negeri Semarang, Semarang.

J. Long R. 1998. Compensation in Canada. ITP Nelson. Canada.

Nugroho, Rakhmat. 2006. Analisis Faktor-Faktor yang Mempengaruhi Kinerja Karyawan (Studi Empiris pada PT. Bank Tabungan Negara (Persero), Cabang Bandung). Tesis. Jurusan Manajemen Universitas Diponegoro, Semarang.

Peraturan Menteri Keuangan Nomor 72 tahun 2016 tentang Uang Makan Pegawai.

Peraturan Pemerintah Nomor 34 tahun 2014 tentang Perubahan Keenam belas atas Peraturan Pemerintah Nomor 7 tahun 1977 tentang Peraturan Gaji Pegawai Negeri Sipil.

Peraturan Pemerintah Nomor 18 tahun 2016 tentang Perangkat Daerah. 
Pratiwi, Riska. 2014. Pengaruh Budaya Organisasi terhadap Kinerja Pegawai pada Kantor Pelayanan Kekayaan Negara dan Lelang Makassar. Skripsi. Universitas Hasanuddin, Makasar.

Rejeki, Anggraeni Tri. 2015. Pengaruh Keadilan Organisasional pada Komitmen Organisasional dengan Kepuasan Kerja sebagai Mediasi (Studi Kasus Pada Karyawan PT Purinusa Eka Persada Bawen). Skripsi. Jurusan Manajemen Fakultas Ekonomi Universitas Negeri Semarang.

Retnaningsih, Sudarwanti. 2007. Analisis Pengaruh Keadilan Kompensasi, Peran Kepemimpinan, dan Kepuasan Kerja terhadap Komitmen Organisasi dalam Meningkatkan Kinerja Karyawan (Studi Kasus: Pada Sentral Pengolahan Pos Semarang). Tesis. Jurusan Manajemen Universitas Diponegoro, Semarang.

Robbins P.S., Timothy A. Judge. 2015. Perilaku Organisasi Edisi 16. Penerbit Salemba Empat: Jakarta.

Suara Merdeka. 2015. Gaji PNS Didasarkan Kelas Jabatan. http://berita.suaramerdeka.com/smcetak/gaji-pnsdidasarkan-kelas-jabatan/, diakses pada 6 April 2017.

Sugiri, Slamet. 2009. Akuntansi Managemen Sebuah Pengantar. UPP STIM YKPN: Yogyakarta.

Sugiyono. 2009. Statistika untuk Penelitian (cetakan ke-19). Alfabeta: Bandung.

Suliyanto. 2005. Analisis Data Dalam Aplikasi Pemasaran. Bogor: Ghalia Indonesia.

Sutrisna, I Wayan Wira, Agoes G.R. 2014. Pengaruh Keadilan Distributif, Prosedural, dan Interaksional terhadap Kepuasan Kerja dan Komitmen Organisasi pada Paramedis Di Rumah Sakit Tk II Udayana Denpasar. Skripsi. Universitas Udayana.

Suwarno,Yogi. 2014. Persepsi Keadilan Gaji PNS DKI Terendah dengan Gaji PNS Pusat. http://www.kompasiana.com/sugarfree/persepsi-keadilan-gaji-pns-dki-terendah-dengan-gaji-pnspusat_54f3ac8d745513a12b6c7caf, diakses pada 28 Maret 2017.

Undang-Undang Republik Indonesia Nomor 5 Tahun 2015 tentang Aparatur Sipil Negara.

Wiryanata, I Gusti Ngurah. 2014. Pengaruh Partisipasi Anggaran, Keadilan Prosedural, Keadilan Distributif, dan Goal Commitment Pada Kinerja Organisasi. Jurnal Magister Akuntansi Fakultas Ekonomi dan Bisnis Universitas Udayana, Bali. 